\title{
Histological Structure of Stingrays (Gymnura poecilura) Heart
}

\author{
Desi Arsita Yani \\ Biology Department, Faculty of Science and Technology, UIN Sunan Kalijaga Yogyakarta \\ Jl. Marsda Adisucipto No 1 Yogyakarta 55281, Indonesia. Tel. +62-274-540971, Fax. +62-274-519739. \\ Email: desiarsita82@yahoo.co.id
}

\begin{abstract}
Yani D A. 2017. Histological Structure of Stingrays (Gymnura poecilura) Heart. Proc Internat Conf Sci Engin 1: 5-7. Stingrays belong to the sub class of Elesmobranchii or often termed as cartilaginous fish. The heart is one of the circulating organs in fish that serves to pump blood throughout the body. The fish circulatory system is a closed system with a single blood circulation. This study aims to determine the histological structure of stingrays' hearts. The fish used for this study are butterfly stingray (Gymnura poecilura) obtained from Depok Beach, Bantul. The equipments used in this research are a set of surgical instrument, bottles, paraffin board, razor blades, embedding cassettes, staining jar, microtomes, slide glass, cover glass, and binocular microscopes. Materials used are stingrays, chloroform, bouin, alcohol, xylol, aquades, paraffins, hematoxylin and eosin, albumin, and entelan. The staining used in this research is HE (Hematoxylin-Eosin) method. Based on the results of the research and observation, the heart of stingrays consists of epicardium, endocardium, myocardium, muscle cells, and cell nuclei. Epicardium is the outermost layer of the heart that is coated by the tissue as a protective. The inner endocardium is coated with epithelial cells. Myocardium are the middle layer of heart wall. The smooth muscle cells are the heart muscle. Cell nuclei are usually present in smooth muscle cells.
\end{abstract}

Keywords: Heart, Histology, Stingray

\section{INTRODUCTION}

Indonesia is a vast archipelagic country with rich natural resources of biodiversity (Nuitja, 2010). Stingray is one of the animals that live in the sea water into the sub class Elesmobranchii or often termed as cartilaginous fish. In addition to cartilaginous fish, this rayfish has a tail like a whip. This stingray has a gill slit located on the ventral side of the head. The fin of the winged stingrays resembles wings (Allen, 2000).

According to Last and Stevens, stingrays have flattened bodies (depressed). When viewed from above, the stingray looks oval-shaped because of the pectoral fins of the stingray's wings and blends with the left and right sides of the head (Schwart, 2007; Henningsen \& Leaf, 2010). Stingrays have gill slits, cloaca, and klasper located on the ventral side of the head. Stingrays in some species are equipped with toxins, which are often called stingrays. The eyes of the stingrays are usually located on the side of head. The position of the mouth of the stingray are terminal. Respiratory apparatus are gill slits that amounts to 5-6 pairs, position is located near the mouth on the ventral.

The size of the adult stingrays are varies. For a relatively small stingray size has a length of $10 \mathrm{~cm}$ and a width of $5 \mathrm{~cm}$. The largest stingray is also known as long manta rays that reach $700 \mathrm{~cm}$ or 7 meters, the width reaches $610 \mathrm{~cm}$ or 6.1 meters, and weight of 1-3 tons (Bond, 1979).

Heart is one of the circulating organs in fish that serves to pump blood throughout the body. The circulatory system of fish in the form of a closed circulatory system or a single blood circulation. The heart lies near the gills and is encased by a membrane called the pericardium (Campbel, 2005). The heart is in the pericardium cavity. It consists of sinus venosus, atrium, ventriculus, and bulbus arteriosus. The sinus wall of venosus, atrium, and ventriculus is contractile, but the bulbus arteriosus wall is not. Bulbus arteriosus is the base of the ventral aorta (Radiopoetro, 1996).

The circulatory system in fish consists of ventricle and atrium. Atrium functions as a low blood container of its oxygen content derived from the entire body and receives oxygen-rich blood coming from the lungs and drains the blood into the ventricles. The ventricle serves to receive blood from the atria and pump it into the lungs. Ventricles serve to pump oxygen-rich blood throughout the body. The heart lies beneath the pharynx within the pericardium cavity, which is part of the body cavity located anteriorly. In addition, there is a sinus venosus organ, a connective structure in the form of a cavity that receives blood from the veins and opens in the front chambers of the heart (Pratiwi, 2007).

The circulatory system of fish is a single blood circulation, which means that blood only once flows through the heart. Blood enters the heart via a vein that is contained in the venous sinus, the blood enters the chamber and then pumped by the artery and into the gill arch, then there will be an exchange of oxygen gas. After that the blood flows back to the heart through the vein (Mahardono, 1979). This study aims to add insight in histology and can be used as a database for further research.

\section{MATERIALS AND METHODS}

This research were done for six months. This research was conducted at Integrated Laboratory of State Islamic University of Sunan Kalijaga Yogyakarta. 
The equipments used in this research are a set of surgical instruments consisting of scissors, tweezers, scalpels, blades, vial bottles, paraffin board, razor blades, embedding cassettes, staining jar, microtome, slide and cover glasses, and binocular microscope.

The materials used for this study are ether or chloroform solutions, fixative solutions are bouin, alcohols, xylol, aquades, paraffin, hematoxylin and eosin, and entelan.

Animals were dissected to be take the organ that would be used as histology. Fixation were done by inserting the organ that will be made histology into bouin solution. The organ dehydrated using a series graded alcohol solution, 50\% alcohol, 60\% alcohol, 70\% alcohol, $80 \%$ alcohol, 90\% alcohol, 96\% alcohol, and absolute. The aim of dehydration is to completely eliminate the water content of the organs. After that, clearing was done to clean up the remnants of alcohol from the organs and help the process for paraffin absorption. This clearing process uses toluene. Infiltration process was done by inserting organs into paraffins in the oven at $70{ }^{\circ} \mathrm{C}$. The purpose of infiltration is to facilitate the cutting. Then after the infiltration, embedding process is done by inserting the organ into the paraffin block. Sectioning organ was done to made sliced organ. The sliced organ were mounted to slide using albumin.

The staining was performed using the HE staining method (Hematoxylin-eosin). The observations were performed using binocular microscope. The histological slide were captured using microscope with $4 \times 10,10 \times$ 10 , and $40 \times 10$ magnification. Data were analyzed using qualitative and descriptive method.

\section{RESULTS AND DISCUSSION}

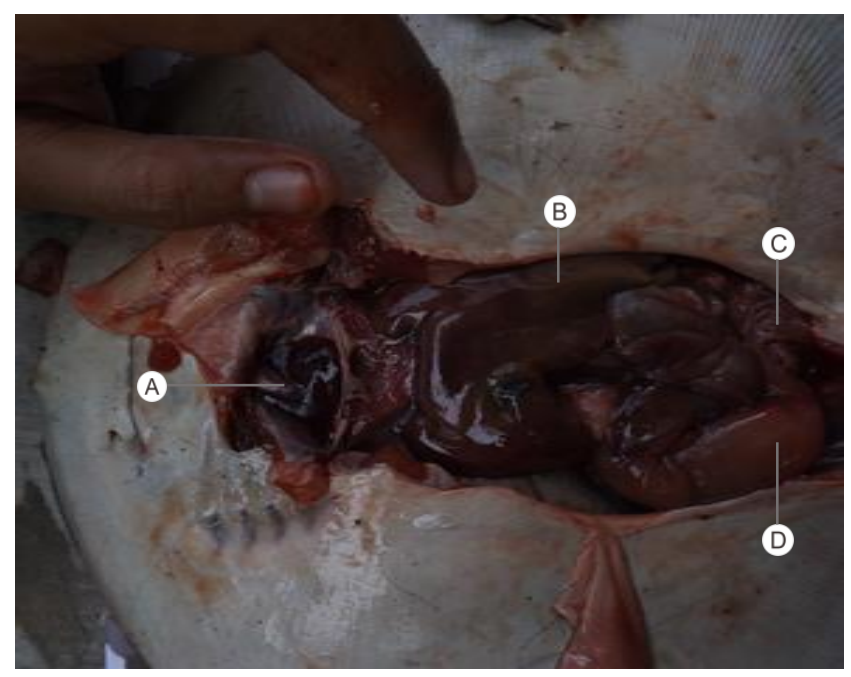

Figure 1. Anatomy of butterfly stingray (Gymnura poecilura) (A) heart, (B) liver, (C) intestine, and (D) stomach.

Stingrays used in this study were butterfly stingrays with no small dorsal fins at the base of the tail or rudiment, dorsal surface of brownish disc with dark and bright colored spots. Maximum body length was about $66 \mathrm{~cm}$, maximum width of $82 \mathrm{~cm}$. The tail length of the cloaca to the end is close to the length of SVL (Snout Vent Length). At the tail there was about 9 thick circular black lines. The distribution of these stingrays are in the Indo-Western Pacific region and also found in the Red Sea, Pakistan, India, Sri Lanka, Indonesia (Java, Sumatra, and Kalimantan).

The digestive organs of the stingrays consist of the mouth, pharynx, esophagus, stomach, intestine, and cloaca. In the fish's mouth there are tooth jaws. Faring is open and associated with five gill slits. Hepar consists of two parts occupying the anterior cavity.

Heart of the stingray consists of thick-walled sinus venosus followed by thick-walled antrium and ventriculum attached to the conus anteriosus then proceeded to the ventral aorta which branches the five pairs of afferent branchial artery. Then through four pairs of blood branchialis afferent enter the dorsal aorta (Djarubito, 1989).

The circulatory system in fish consists of ventricle and atrium. The heart lies beneath the pharynx within the pericardium cavity, which is part of the body cavity located anteriorly. In addition, there is a sinus venosus organ, a connective structure in the form of a cavity that receives blood from the veins and opens in the front chambers of the heart.

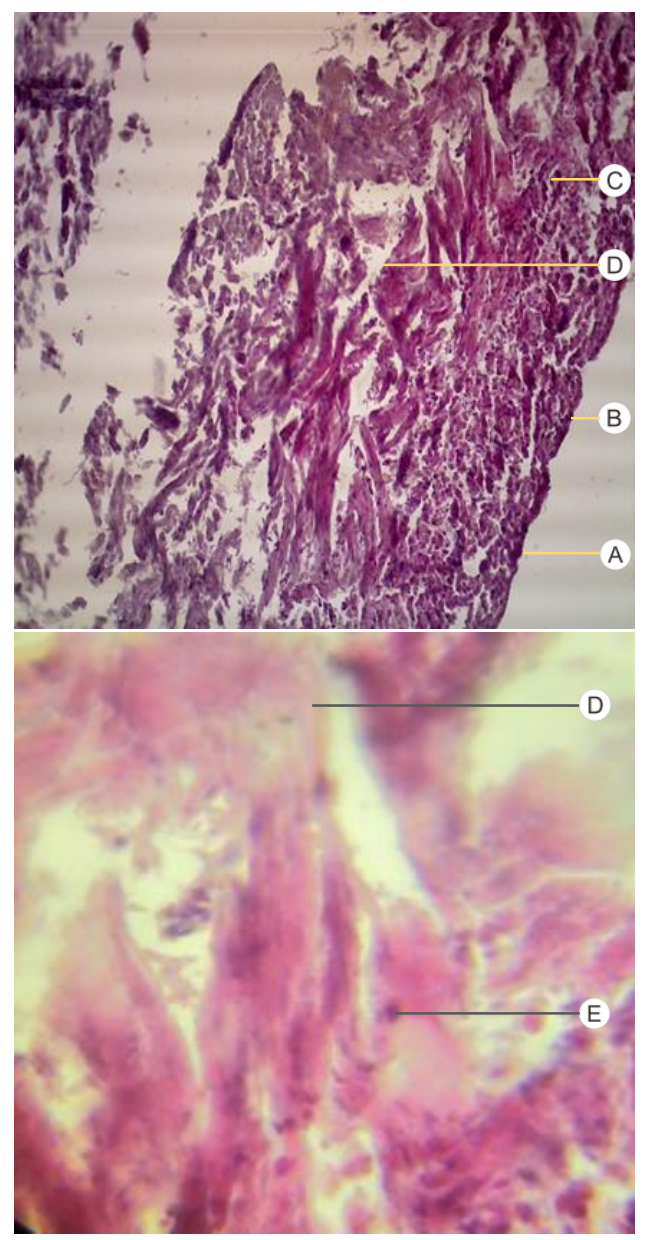

Figure 2. Histology cross-section of the heart of the stingray (A Epicardium, B. Endocardium, C. Myocardium, D. Smooth muscle cell, E. cell nucleus.) 
Myocardium is a cardiac muscle arranged in layers covering the spiral heart chambers, on the preparation, muscles arranged seen in irregular directions. The function of the myocardium is to stimulate the contraction of the heart to pump blood from the ventricles and relax the heart to allow the atrium to receive blood. The endocardium is coated by a flat epithelial layer called the endothelium. The epicardium layer is the outermost layer of the outer heart that is covered by a layer of mesothelium cells supported by a loose connective tissue containing venous, nerve, and ganglia nerves. In the epicardium layer there is also an adipose tissue that protects the heart (Junqueira \& Carneiro, 2005). The smooth muscle cells are muscle tissue contracting unconsciously and cannot be interventionally conscious. Smooth muscle cells can be found on the walls of organs. The function of smooth muscle cells is to determine the flow of blood in the arteries. The heart of the oval-shaped heart cells is on the edge of the cell. The core location at the edge of the cell distinguishes skeletal muscle from the heart muscle and smooth muscle (Eroschenko, 2003).

\section{CONCLUSIONS}

Based on the results of observation and analysis it can be concluded that heart organ of stingray has the same basic structure with the heart of other fish. In the cross section of the heart of the stingrays, there is a structure consisting of epicardium, endocardium, myocardium, cell nucleus, and smooth muscle cells.

\section{REFERENCES}

Allen, G. 2000. Marine Fishes Of South and East Asia. A Field Guide For Anglers and Diversi. Western Australia.

Bond, CE. 1979. Biology of fishes. Philadephia: W.B. Saunders Company.

Bone and Marshall. 1982. Perubahan Jaringan Ginjal dan Gonad Ikan Pari (Dasyatis kuhlii, Muller \& Henle, 1841) Akibat Toksisitas Logam Seng ( $\mathrm{Zn}$ ). Skripsi. Jurusan Perikanan. Universitas Hasanuddin. Makassar.

Campbell N.A dan Reece J.B. 2005. Biology. Edisi ke-7. San Fransisco: Pearson Benjamin Cummings.

Djarubito, Mukayat. 1989. Zoologi Dasar. Jakarta: Erlangga.

Eroschenko, Victor P. Atlas Histologi di Fiore dengan Korelasi Fungsional/ Victor P. Eroschenko: alihbahasa, Jan Tambayong; editor edisi Bahasa Indonesia, Dwi Angraini.Ed.9- Jakarta: EGC.2003.

Fujaya \& Yushinta. 2001. Fisiologi Ikan. Jakarta: PT. Rineka Cipta

Henningsen AD, RT Leaf. 2010. Observations on the Biology of the American Fisheries Society. 139:783-791.

Junqueira, L.C. and J. Carneiro. 2005. Basic Histology $11^{\text {th }}$ editions. Mc Graw Hill, Sao Paulo, Brazil p: 308-324.

Mahardono, A., S. Pratignyo., S. Iskandar. 1979. Anatomi Ikan. Surabaya: Intermesa.

Olivetti G, Cigola E, dan Maestri R. 1996. Agging, Cardiac Hypertrophy and Ishemic Cardio Myopathy Do Not Affect the Proportion of Monocleated and Multinucleated Myocytes in the Human Heart. J. Mol. Cell. Cardiol

Radiopetro. 1996. Zoologi. Jakarta: Erlangga.

Schwartz, FJ. 2007. A Survey of Tail Spine Characteristics of Stingtrays Frequenting African, Arabian to Chagos-Maldive Archipelago Waters. Smithiana Bulletin 8:41-52.

Yuliani, Sri. 2002. Anatomi dan Fisiologi Untuk Paramedis. Jakarta: Erlangga. 
THIS PAGE INTENTIONALLY LEFT BLANK 